\title{
CDK11B wt Allele
}

National Cancer Institute

\section{Source}

National Cancer Institute. CDK11B wt Allele. NCI Thesaurus. Code C49447.

Human CDK11B wild-type allele is located in the vicinity of 3p21 and is approximately 31 $\mathrm{kb}$ in length. This allele, which encodes cyclin-dependent kinase 11B protein, plays a role in proliferation regulation, apoptosis and is essential for eukaryotic cell cycle control. The allele is deleted or altered frequently in neuroblastoma with amplified MYCN genes. 